\title{
Comparisons among the amino acid composition of females, eggs and food to determine the relative importance of food quantity and food quality to copepod reproduction
}

\author{
Cástor Guisande*, Isabel Riveiro, Isabel Maneiro \\ Facultad de Ciencias del Mar, Universidad de Vigo, Aptdo. 874, 36200 Vigo, Spain
}

\begin{abstract}
A field study was carried out to determine the relative importance of both food quantity and food quality to reproduction of the copepod Euterpina acutifrons. The total protein concentration of the seston 3 to $20 \mu \mathrm{m}$ size fraction was used as the indicator of food available for copepods in the field. Food quality was quantified by comparing the amino acid (AA) composition of females, eggs and the seston 3 to $20 \mu \mathrm{m}$ size fraction, and by considering the species composition of the phytoplankton community. Egg production rate was mainly determined by food concentration. However, for the same food concentration, a reduced egg production rate was observed when there were more differences between the AA composition of eggs and females. Hatching success was correlated only with food quality. A higher hatching success was obtained when the similarity between the AA composition of eggs and females and between the AA composition of females and seston was higher. However, a reduced hatching success was observed when the proportion of diatoms in the phytoplankton was higher than $70 \%$. Therefore, food quality limitation was due to an AA imbalance in the natural seston and, perhaps, due to the presence of inhibitory compounds. Copepods were food limited for long periods of the year. Food quality mainly limited copepod reproduction in spring and early summer, whereas food quantity limited reproduction at the end of autumn and early winter. In summer and early autumn the reproductive success of copepods was higher.
\end{abstract}

KEY WORDS: Zooplankton · Copepods · Food limitation · Food quality $\cdot$ Reproduction $\cdot$ Amino acids · Egg production $\cdot$ Hatching success

\section{INTRODUCTION}

It has been shown that both food quantity and food quality are important biotic factors affecting copepod reproductive success in the field (see Kleppel 1993). However, it is still unknown whether egg production rate and hatching viability are affected more by food quantity or by food quality.

Egg production rate is generally hyperbolically related to food concentration in copepods (Checkley 1980, Runge 1985). However, it is not clear whether

*E-mail: castor@uvigo.es egg hatching success is also affected by food availability. It has been shown in some copepod species that there is a trade-off between egg size and egg number (Guisande et al. 1996, Pond et al. 1996), which can be interpreted as a reproductive strategy to maximize reproductive success under low and high food concentrations (Hutchinson 1967). On the other hand, it has been shown in the copepod Calanus helgolandicus that egg hatching success increased with egg size (Guisande \& Harris 1995). Therefore, if larger eggs are produced at low food concentrations and egg viability increases with egg size, food concentration could indirectly be affecting egg hatching success. However, other field studies found no significant relationship 
between egg size and egg viability in copepods (Pond et al. 1996, Tang et al. 1998).

Food quality affects both egg production rate (Huntley et al. 1987, Jónasdóttir 1994, Jónasdóttir et al. 1995, Kleppel \& Burkart 1995, Jónasdóttir \& Kiørboe 1996) and egg viability in copepods (Ianora et al. 1992, Ianora \& Poulet 1993, Laabir et al. 1999). Although food quality depends on particle size, morphology, taxonomic composition, digestion resistance, nutritional value and toxicity (see Kleppel \& Burkart 1995), in the end it is largely the nutritional composition of the food mixture that determines its impact on copepod reproduction (Cahoon 1981, Huntley et al. 1987, Jónasdóttir 1994, Kleppel \& Burkart 1995, Jónasdóttir \& Kiørboe 1996, Sanders et al. 1996, Koski et al. 1998). Nutritional inadequacy in zooplankton has been related to either elemental limitation ( $P$ and/or N) (Checkley 1980, Ambler 1986, Sterner 1993, Urabe et al. 1998) or biochemical limitations in terms of specific fatty acid deficiencies (Støttrup \& Jensen 1990, Jónasdóttir 1994, Jónasdóttir \& Kiørboe 1996, Müller-Navarra \& Lampert 1996, Kleppel et al. 1998) or amino acid (AA) deficiencies (Kleppel et al. 1998). Therefore, the C:P:N ratio, the fatty acid composition and/or the AA composition of the food can be used to quantify food quality.

However, it is known that toxins (Nejstgaard \& Solberg 1996, Turner et al. 1998) and inhibitory compounds (Miralto et al. 1999) also affect egg hatching success of copepods. Laabir et al. (1999) showed that egg hatching success in Calanus helgolandicus feeding on the diatom Phaeodactylum tricornutum was low, and the inhibition of hatching success related to the ingestion of $P$. tricornutum was not due to a lack of any AA. Therefore, the presence of deleterious toxins or inhibitors could invalidate the use of the elemental or biochemical composition of the food as a measurement of egg quality.

Another approach to quantify food quality is to compare the AA composition of the females to the AA composition of the eggs. It has been shown in the copepod Euterpina acutifrons that there is homeostasis at a biochemical level because AA is constant in adults of this copepod species despite different nutritional supplies (Guisande et al. 1999). However, this study also showed that egg AA varied according to food source. A higher reproductive success was observed when the AA composition of females and the eggs was similar (Guisande et al. 1999). If, in addition to nutritional inadequacy, AA composition of eggs is also affected by other attributes of the food, a comparison between the AA composition of copepods and composition of eggs could be used to quantify the effect of food quality on copepod reproduction.
The aim of this field study carried out with the marine copepod Euterpina acutifrons was to determine the importance of both food quantity and food quality on copepod reproduction.

\section{METHODS}

The study was carried out from March 1998 to January 1999 at a field station (39 $\mathrm{m}$ deep) located in Ría de Vigo, Spain $\left(42^{\circ} 13.3^{\prime}\right.$ N, $\left.8^{\circ} 47.7^{\prime} \mathrm{W}\right)$. The copepods were collected monthly between 12:00 and 13:00 h by vertically integrated plankton tows from a depth of $20 \mathrm{~m}$ to the surface. In order to estimate egg production rate, hatching success, naupliar size and naupliar production rate, 10 to 20 gravid females were isolated within $4 \mathrm{~h}$ of collection and individually transferred to $20 \mathrm{ml}$ containers with $20 \mu \mathrm{m}$ filtered seawater from the sampling station. Copepods were maintained for $3 \mathrm{~d}$ at $15^{\circ} \mathrm{C}$ and transferred daily to fresh suspensions of this seston size fraction $(<20 \mu \mathrm{m})$, and the number of egg sacs laid and nauplii produced by females were counted. Copepod mortality during the $3 \mathrm{~d}$ of incubation was never higher than $1 \%$. The embryonic development period in Euterpina acutifrons at $15^{\circ} \mathrm{C}$ is approx. $3 \mathrm{~d}$ (Zurlini et al. 1978); thus, it was necessary to allow $3 \mathrm{~d}$ for freshly laid eggs to hatch. To estimate egg hatching success only the nauplii from the first sac were taken into account. Between 10 and 20 gravid females were also removed from the sample in order to estimate the number of eggs per sac.

Phytoplankton abundance data were obtained from the monitoring carried out by Centro de Control do Medio Mariño (Xunta de Galicia). Samples were collected weekly at a station close to the one mentioned above $\left(42^{\circ} 16.0^{\prime} \mathrm{N}, 8^{\circ} 43.1^{\prime} \mathrm{W}\right)$, using plastic columns from 0 to 5,5 to 10 and 10 to $15 \mathrm{~m}$ and immediately fixed in Lugol's iodine solution. These samples were mixed, homogenized and allowed to settle in Utermöhl chambers; $25 \mathrm{ml}$ of this mixture were counted to obtain the mean abundance in the water column for each phytoplankton species.

An AA analysis of females and eggs was performed on gravid females isolated from the samples. There are no data on AA of eggs from December 1998 because there were not enough gravid females to carry out the analyses. AA of females and eggs were performed on samples containing 3 females and 3 egg sacs, respectively.

Nitrogen is an important limiting factor for marine copepods (Checkley 1980, Ambler 1986). For this reason, total protein concentration has been shown to be a good indicator of food availability for copepods in the field (Guisande et al. 1996, Guisande et al. 1999). Sea- 
water samples collected at a 2, 5, 10, 15 and $20 \mathrm{~m}$ depth at the field station were combined in order to analyze AA and total protein concentration of the seston 3 to $20 \mu \mathrm{m}$ size fraction. This size fraction is within the range of particles effectively captured by adult Euterpina acutifrons (Kinne 1977). Because the depth distribution of copepods may vary during the day, food concentrations taken at several standard depths were combined and served as a good indicator of the average food concentration available for $E$. acutifrons throughout the entire water column (Guisande et al. 1996, 1999). Total protein and AA analyses were performed on GF/C-filtered material of the seston 3 to $20 \mu \mathrm{m}$ size fraction integrated with seawater samples from the depths mentioned above. The volume filtered ranged from 100 to $150 \mathrm{ml}$.

AAs of females, eggs and seston were analyzed from 4 to 6 replicates by HPLC using an Alliance system, a 474 scanning fluorescence detector and a $15 \times 3.9$ Nova-Pak $\mathrm{C}_{18}$ column following the method described by van Wandelen \& Cohen (1997). Amino acid Standard H No. NCI0180 PIERCE was used for the identification and quantification of the amino acids.

Total protein was analyzed from 5 to 6 replicates. The method described by Lowry et al. (1951) and modified by Markwell et al. (1978) was used to analyze total proteins.

Average Euclidean distance was used to estimate similarity between the AA composition of females and of seston and eggs (Guisande et al. 1999). A higher similarity is obtained when the Euclidean distance is smaller.

\section{RESULTS}

Tables 1, 2 \& 3 show the AA composition of the seston 3 to $20 \mu \mathrm{m}$ size fraction and of Euterpina acutifrons females and eggs in spring, summer, autumn and winter. When the AAs of seston, females and eggs were grouped by seasons, the pattern of variation showed by seston and eggs was the same along functions I and II of a discriminant analysis, with the exception of winter (Fig. 1). Therefore, egg AAs varied according to the AAs of the food source.

AAs of the seston varied over the year. This was confirmed by a 2-level nested analysis of variance (ANOVA) which showed that, although most of the variation in the proportion of the AAs in the seston occurred among AAs $\left(F_{14,150}=\right.$ $359.9, \mathrm{p}<0.001,95.6 \%$ of variance), there were also significant differences among months for individual AAs $\left(F_{150,735}=9.4, \mathrm{p}<0.001,2.6 \%\right.$ of variance $)$.

An analysis of copepod AAs showed that, although there was no strict homeostasis, despite different environmental conditions, most of the AAs of Euterpina acutifrons females remained constant over the year. Two-level nested ANOVA showed that there were significant differences among the proportion of the AAs in females $\left(F_{14,105}=384.9, \mathrm{p}<0.001,94.5 \%\right.$ of variance $)$ and among months for individual AAs $\left(F_{105,418}=1.9\right.$, $\mathrm{p}<0.001,0.9 \%$ of variance). However, when proline,

Table 1. Essential amino acid composition (mean \pm SD weight percentage of total amino acids yield) of the seston 3 to $20 \mu \mathrm{m}$ size fraction (in spring, summer, autumn and winter). Amino acid abbreviations: ASP, aspartic acid; SER, serine; GLU, glutamic acid; GLY, glycine; HIS, histidine; ARG, arginine; THR, threonine; ALA, alanine; PRO, proline; TYR, tyrosine; VAL, valine; LYS, lysine; ILE, isoleucine; LEU, leucine; PHE, phenylalanine

\begin{tabular}{|lrrrr|}
\hline & \multicolumn{1}{c}{ Spring } & \multicolumn{1}{c}{ Summer } & \multicolumn{1}{c|}{ Autumn } & \multicolumn{1}{c|}{ Winter } \\
\hline ASP & $9.6 \pm 0.6$ & $9.9 \pm 0.7$ & $8.9 \pm 1.6$ & $9.3 \pm 0.4$ \\
SER & $10.4 \pm 1.2$ & $11.4 \pm 1.2$ & $10.3 \pm 0.6$ & $11.6 \pm 0.3$ \\
GLU & $14.6 \pm 0.6$ & $14.6 \pm 1.0$ & $14.4 \pm 0.5$ & $14.8 \pm 0.4$ \\
GLY & $11.3 \pm 0.9$ & $11.7 \pm 1.1$ & $11.4 \pm 0.5$ & $12.4 \pm 0.6$ \\
HIS & $3.0 \pm 0.7$ & $2.8 \pm 0.2$ & $2.9 \pm 0.4$ & $3.7 \pm 0.7$ \\
ARG & $5.6 \pm 0.3$ & $5.8 \pm 0.5$ & $5.9 \pm 0.3$ & $6.0 \pm 0.4$ \\
THR & $4.9 \pm 0.3$ & $4.9 \pm 0.5$ & $5.1 \pm 0.3$ & $4.5 \pm 0.1$ \\
ALA & $4.8 \pm 0.7$ & $5.0 \pm 0.8$ & $5.2 \pm 0.5$ & $4.4 \pm 0.1$ \\
PRO & $3.6 \pm 0.4$ & $3.2 \pm 0.5$ & $3.7 \pm 0.5$ & $3.6 \pm 0.5$ \\
TYR & $4.0 \pm 0.8$ & $4.7 \pm 0.6$ & $4.5 \pm 0.4$ & $3.7 \pm 0.7$ \\
VAL & $4.4 \pm 0.5$ & $4.1 \pm 0.4$ & $4.6 \pm 0.2$ & $3.9 \pm 0.1$ \\
LYS & $7.4 \pm 0.7$ & $6.7 \pm 0.6$ & $6.9 \pm 0.9$ & $6.8 \pm 0.7$ \\
ILE & $4.5 \pm 0.8$ & $4.0 \pm 0.4$ & $4.1 \pm 0.6$ & $3.9 \pm 0.2$ \\
LEU & $7.4 \pm 0.5$ & $7.4 \pm 0.4$ & $7.5 \pm 0.9$ & $7.2 \pm 0.3$ \\
PHE & $4.3 \pm 0.3$ & $3.8 \pm 0.6$ & $4.6 \pm 0.9$ & $3.8 \pm 0.3$ \\
& & & & \\
\hline
\end{tabular}

Table 2. Essential amino acid composition (mean \pm SD weight percentage of total amino acids yield) of Euterpina acutifrons females (in spring, summer, autumn and winter). Amino acid abbreviations as shown in Table 1

\begin{tabular}{|lrrrrr|}
\hline & \multicolumn{1}{c}{ Spring } & Summer & \multicolumn{1}{c}{ Autumn } & \multicolumn{1}{l}{ Winter } & Pooled mean \\
\hline ASP & $8.7 \pm 0.5$ & $9.0 \pm 0.1$ & $8.9 \pm 0.2$ & $8.8 \pm 0.3$ & $8.8 \pm 0.4$ \\
SER & $4.9 \pm 0.6$ & $4.8 \pm 0.5$ & $4.6 \pm 0.2$ & $5.2 \pm 0.7$ & $4.9 \pm 0.6$ \\
GLU & $13.9 \pm 1.1$ & $14.2 \pm 0.1$ & $14.0 \pm 0.4$ & $13.9 \pm 0.6$ & $13.9 \pm 0.9$ \\
GLY & $6.2 \pm 0.6$ & $6.3 \pm 0.2$ & $6.3 \pm 0.2$ & $6.9 \pm 0.6$ & $6.5 \pm 0.6$ \\
HIS & $2.6 \pm 0.1$ & $2.3 \pm 0.1$ & $2.5 \pm 0.2$ & $2.6 \pm 0.2$ & $2.5 \pm 0.2$ \\
ARG & $9.3 \pm 1.4$ & $9.9 \pm 0.3$ & $9.3 \pm 1.6$ & $9.1 \pm 0.9$ & $9.4 \pm 1.2$ \\
THR & $4.8 \pm 0.3$ & $4.8 \pm 0.2$ & $5.3 \pm 0.9$ & $4.9 \pm 0.2$ & $4.9 \pm 0.4$ \\
ALA & $7.8 \pm 0.5$ & $8.4 \pm 0.1$ & $7.9 \pm 0.4$ & $8.0 \pm 0.2$ & $7.9 \pm 0.4$ \\
PRO & $6.3 \pm 0.5$ & $5.1 \pm 0.5$ & $5.8 \pm 0.4$ & $5.6 \pm 0.6$ & $6.0 \pm 0.6$ \\
TYR & $6.8 \pm 1.0$ & $7.5 \pm 0.9$ & $7.5 \pm 1.0$ & $6.7 \pm 1.3$ & $6.9 \pm 1.1$ \\
VAL & $5.4 \pm 0.2$ & $4.8 \pm 0.1$ & $5.4 \pm 0.2$ & $5.5 \pm 0.1$ & $5.4 \pm 0.2$ \\
LYS & $7.8 \pm 0.6$ & $8.5 \pm 0.1$ & $7.3 \pm 0.2$ & $7.0 \pm 0.7$ & $7.5 \pm 0.7$ \\
ILE & $4.9 \pm 0.2$ & $4.1 \pm 0.1$ & $4.8 \pm 0.1$ & $5.0 \pm 0.5$ & $4.9 \pm 0.4$ \\
LEU & $7.1 \pm 0.3$ & $6.7 \pm 0.1$ & $7.0 \pm 0.2$ & $7.0 \pm 0.2$ & $7.0 \pm 0.3$ \\
PHE & $3.3 \pm 0.3$ & $3.0 \pm 0.1$ & $3.1 \pm 0.9$ & $3.3 \pm 0.1$ & $3.3 \pm 0.4$ \\
& & & & & \\
\hline
\end{tabular}


Table 3. Essential amino acid composition (mean \pm SD weight percentage of total amino acids yield) of Euterpina acutifrons eggs (in spring, summer, autumn and winter). Amino acid abbreviations as shown in Table 1

\begin{tabular}{|lrrrr|}
\hline & Spring & Summer & Autumn & \multicolumn{1}{c|}{ Winter } \\
\hline ASP & $6.7 \pm 1.7$ & $6.2 \pm 1.4$ & $7.6 \pm 1.4$ & $8.8 \pm 1.8$ \\
SER & $6.4 \pm 1.2$ & $5.6 \pm 1.0$ & $6.1 \pm 1.1$ & $6.8 \pm 1.7$ \\
GLU & $17.0 \pm 2.4$ & $14.6 \pm 2.0$ & $14.8 \pm 2.7$ & $15.4 \pm 3.2$ \\
GLY & $4.9 \pm 0.7$ & $5.3 \pm 0.7$ & $5.1 \pm 0.3$ & $5.5 \pm 0.4$ \\
HIS & $3.1 \pm 0.3$ & $2.7 \pm 0.2$ & $2.8 \pm 0.3$ & $2.4 \pm 0.9$ \\
ARG & $10.4 \pm 2.5$ & $11.8 \pm 1.1$ & $11.7 \pm 0.8$ & $8.8 \pm 2.1$ \\
THR & $5.0 \pm 4.2$ & $5.3 \pm 0.3$ & $4.9 \pm 0.4$ & $5.4 \pm 1.7$ \\
ALA & $5.5 \pm 1.7$ & $5.7 \pm 0.2$ & $5.6 \pm 0.3$ & $7.5 \pm 4.2$ \\
PRO & $5.6 \pm 2.2$ & $8.4 \pm 1.7$ & $7.2 \pm 1.1$ & $6.3 \pm 0.5$ \\
TYR & $4.9 \pm 0.8$ & $5.2 \pm 0.6$ & $5.1 \pm 0.8$ & $4.9 \pm 1.1$ \\
VAL & $5.2 \pm 0.3$ & $4.8 \pm 0.2$ & $5.1 \pm 0.3$ & $5.2 \pm 0.6$ \\
LYS & $9.9 \pm 0.9$ & $9.9 \pm 0.5$ & $8.5 \pm 1.4$ & $8.1 \pm 2.6$ \\
ILE & $4.5 \pm 0.4$ & $4.4 \pm 0.5$ & $4.7 \pm 0.3$ & $4.5 \pm 0.6$ \\
LEU & $6.6 \pm 0.5$ & $6.4 \pm 0.2$ & $6.4 \pm 0.4$ & $6.7 \pm 1.8$ \\
PHE & $3.8 \pm 0.4$ & $3.5 \pm 0.3$ & $4.0 \pm 0.4$ & $3.7 \pm 0.8$ \\
\hline
\end{tabular}

tyrosine and lysine were not included, there were significant differences among AAs $\left(F_{11,84}=328.2, \mathrm{p}<\right.$ $0.001,96.5 \%$ of variance), but AAs did not vary significantly among the different months $\left(F_{84,312}=1.1, \mathrm{p}>\right.$ $0.05,0.1 \%$ of variance). A test for goodness of fit (G-test) showed that there were not significant differences $\left(G=0.68<\chi^{2}{ }_{.05[1]}=3.841, \mathrm{p}>0.05\right)$ between the pooled mean AA of females obtained in this field study and the pooled mean AAs of females of $E$. acutifrons fed different monoalgal diets (Guisande et al. 1999). As there were not important differences in the AA composition of females over the year, to estimate the similarities among AAs of eggs, females and seston, the pooled mean of AAs of females shown in Table 2 was used.

Unlike the constant amino acids in copepods, the percentage of most egg AAs varied significantly between months. Two-level nested ANOVA showed that there were significant differences among the proportion of the AAs $\left(F_{14,135}=94.7, \mathrm{p}<0.001,84.2 \%\right.$ of variance) and among months for individual AAs $\left(F_{135,450}=\right.$ $4.1, \mathrm{p}<0.001,6.9 \%$ of variance). If only the percentages of threonine, tyrosine and leucine are considered, there were significant differences among $\mathrm{AAs}\left(F_{2,27}=\right.$ $60.0, \mathrm{p}<0.001,58.1 \%$ of variance), but the proportion of these AAs in the eggs did not vary significantly over the year $\left(F_{27,90}=0.9, \mathrm{p}>0.05,0.1 \%\right.$ of variance $)$.

The number of eggs per sac was related to the food concentration available to the copepods in the seston 3 to $20 \mu \mathrm{m}$ size fraction (Fig. 2). In December 1998 and in January 1999, a low number of eggs per sac was obtained compared to the high level of food concentration available to the copepods (Fig. 2, shaded symbols). The mean temperatures of the water column (from a
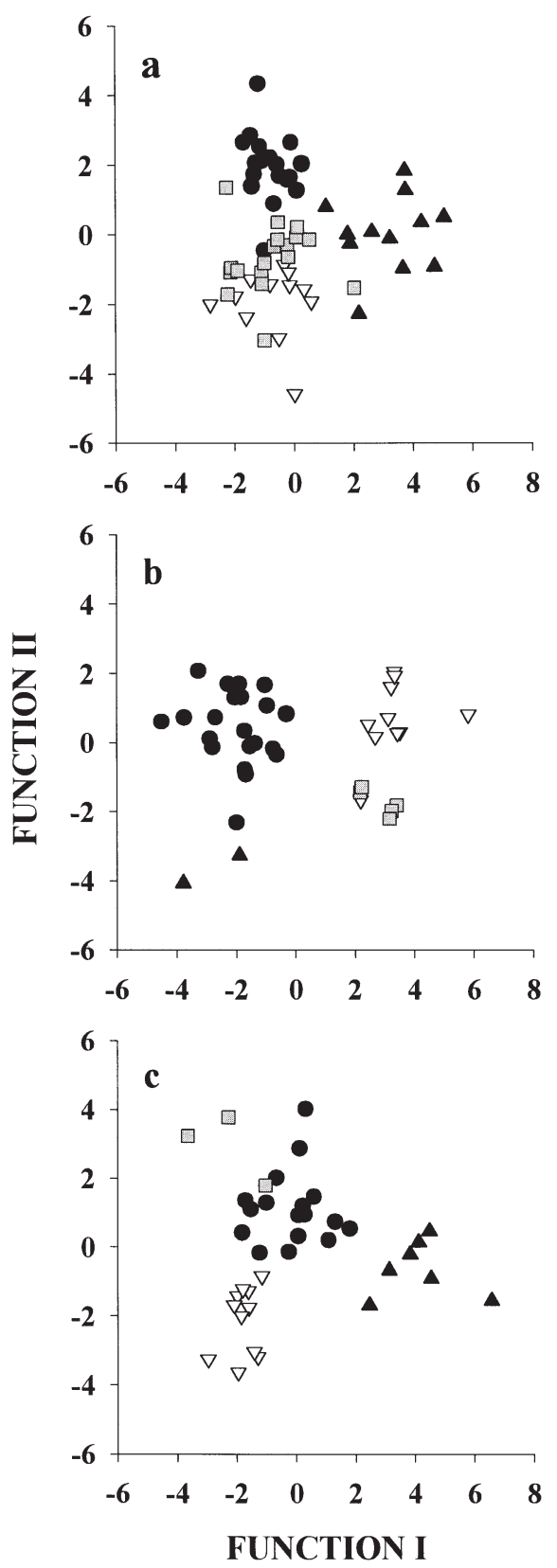

Fig. 1. Scores for the first 2 functions of the discriminant analysis for the AAs of (a) the seston 3 to $20 \mu \mathrm{m}$ size fraction and (b) the females and (c) the eggs of Euterpina acutifrons from monthly data obtained in spring $(\bullet)$, summer $(\boldsymbol{\Delta})$, autumn $(\nabla)$ and winter $(\square)$

depth of $20 \mathrm{~m}$ to the surface) in December 1998 $\left(12.9^{\circ} \mathrm{C}\right)$ and in January $1999\left(13.1^{\circ} \mathrm{C}\right)$ were lower than temperatures in the other months (which ranged between 14.0 and $15.2^{\circ} \mathrm{C}$ with a mean \pm SD of $14.5 \pm$ $0.4^{\circ} \mathrm{C}$ ). When a comparison was made using the number of eggs per sac at high (higher than $13.5^{\circ} \mathrm{C}$ ) and low (lower than $13.5^{\circ} \mathrm{C}$ ) temperatures of the water column as a factor and food concentration (in mg protein 


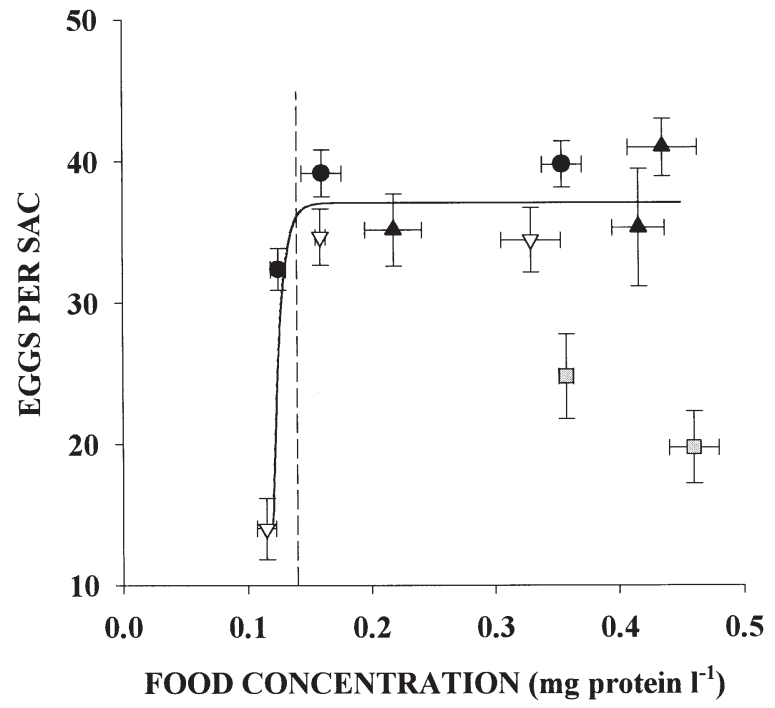

Fig. 2. Relationship between mean $\pm \mathrm{SE}$ of number of eggs per sac $(S)$ and food concentration $\left(P, \mathrm{mg}\right.$ protein $\mathrm{l}^{-1}$ of the seston 3 to $20 \mu \mathrm{m}$ size fraction) in Euterpina acutifrons from monthly data obtained at the field station. Symbols as shown in Fig. 1. Dashed line shows approximately the food concentration above which a maximum number of eggs per sac is reached. Ivlev's fit to the data was $S=37.1\left(1-\mathrm{e}^{-159.0(P-0.12)}\right), F_{1,7}=467.3$, $\mathrm{r}^{2}=0.91, \mathrm{p}<0.001 .(\square)$ December 1998 and January 1999 . These values were not included when calculating the Ivlev curve

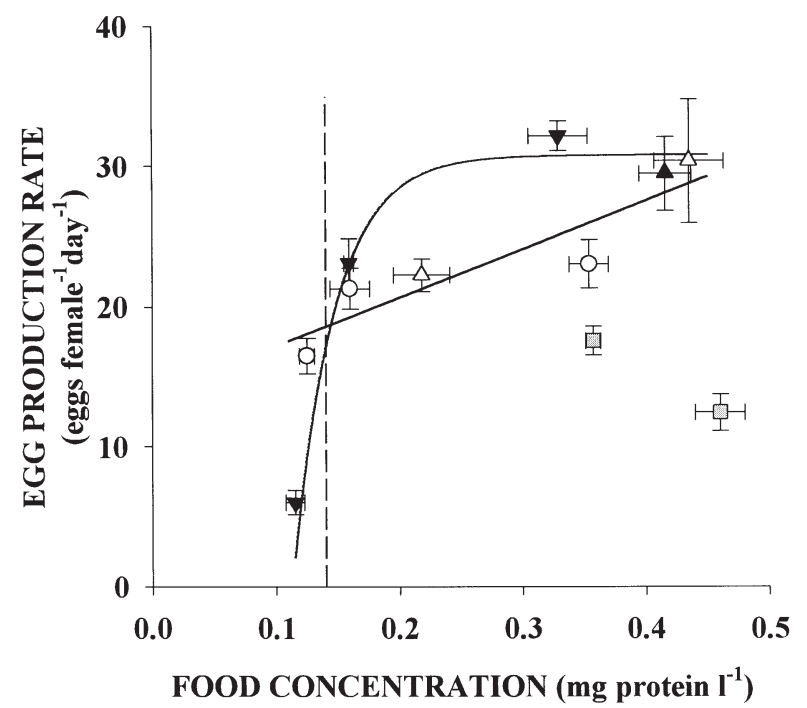

Fig. 3. Relationship between mean \pm SE of egg production rate $\left(E\right.$, in eggs female $\left.{ }^{-1} \mathrm{~d}^{-1}\right)$ and food concentration $(P, \mathrm{mg}$ protein $\mathrm{l}^{-1}$ of the seston 3 to $20 \mu \mathrm{m}$ size fraction) in Euterpina acutifrons from monthly data obtained in the field station. Similarity between female and egg AA composition higher (open symbols) and lower (solid symbols) than 1.5 is shown. For a similarity between AA composition of females and eggs lower than 1.5, Ivlev's fit to the data was $S=30.8$ $\left(1-\mathrm{e}^{-29.4(P-0.112)}\right), F_{1,2}=216.1, \mathrm{r}^{2}=0.99, \mathrm{p}<0.001$; at a similarity between AA composition of females and eggs higher than $1.5, S=13.7+34.4 P, F_{1,3}=13.7, \mathrm{r}^{2}=0.82, \mathrm{p}=0.034$. Symbols and dashed line as described in Figs. 1 \& 2, respectively $\mathrm{ml}^{-1}$ ) as the covariable (ANCOVA, $F_{1,97}=34.6, \mathrm{p}<$ $0.001)$, significant differences were found. These results are in agreement with other studies which have shown that reproduction in Euterpina acutifrons is affected by small changes in temperature (Haq 1972, D'Apolito \& Stancyk 1979). In natural populations of E. acutifrons, the highest number of eggs per sac are obtained when the sea-surface temperature is between 15 and $16^{\circ} \mathrm{C}$ (Haq 1972), and reproduction nearly ceases when the temperature falls to $11^{\circ} \mathrm{C}$ (Haq 1972, D'Apolito \& Stancyk 1979). As it was not possible to distinguish effects of temperature from food concentration and food quality, these 2 months were not included in the parameters that are affected by temperature (egg and naupliar production).

At food concentrations approximately higher than $0.14 \mathrm{mg}$ protein $\mathrm{l}^{-1}$ there were no significant differences in the number of eggs per sac (ANOVA, $F_{6,62}=$ $1.4, \mathrm{p}=0.201)$, with a pooled mean $\pm \mathrm{SD}$ of $35.8 \pm$ 7.2 eggs per sac (Fig. 2).

Fig. 3 shows that egg production rate was also mainly determined by food concentration. However, food quality also affects egg production. This was indicated by significant differences in egg production rates, with a similarity between the AA composition of females and eggs lower and higher than 1.5, taking the covariate food quantity into account (Fig. 2, ANCOVA, $F_{1,125}=4.2, \mathrm{p}=0.042$ ).

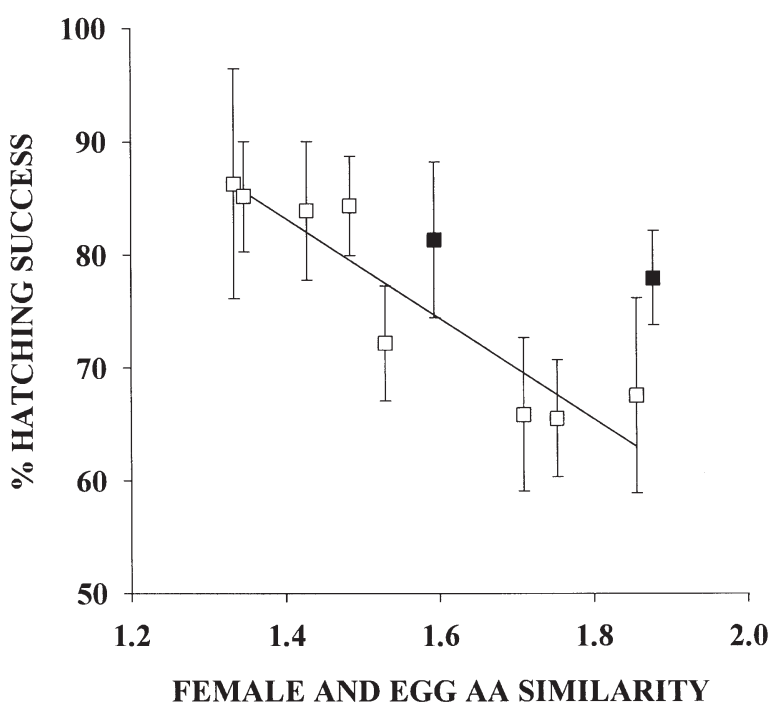

Fig. 4. Relationship between hatching success $(H$, mean \pm SE) and similarity between the AA composition of females and eggs $(A)$ in Euterpina acutifrons. Naupliar body length at hatching smaller $(\square)$ and larger $(\mathbf{\square})$ than $100 \mu \mathrm{m} . H=145.1-$ $44.2 A, F_{1,6}=33.5, \mathrm{r}^{2}=0.85, \mathrm{p}=0.001$. Values with naupliar body length larger than $100 \mu \mathrm{m}$ at hatching are not included in the regression 


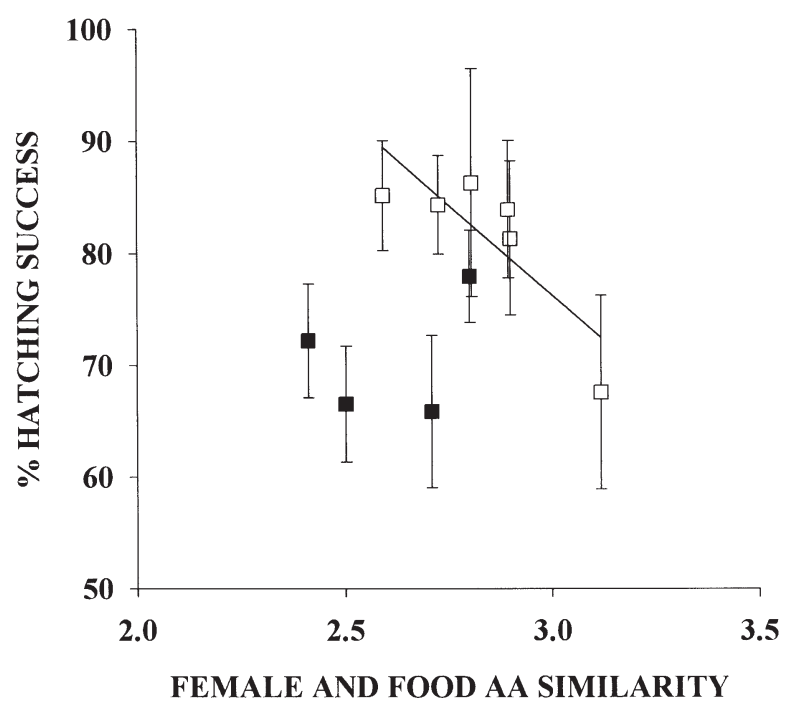

Fig. 5. Relationship between hatching success $(H$, mean $\pm \mathrm{SE})$ and similarity between the AA composition of females and the seston 3 to $20 \mu \mathrm{m}$ size fraction $(B)$. Percentage of diatoms in the phytoplankton community lower $(\square)$ and higher ( $\square$ ) than $70 \% . H=145.1-44.2 B, F_{1,4}=8.1, \mathrm{r}^{2}=0.67, \mathrm{p}=0.046$. Values with percentage of diatoms higher than $70 \%$ are not included in the regression

However, in contrast to egg production, hatching success was mainly affected by food quality rather than by food quantity. Hatching success was only correlated with the similarity between the AA composition of females and eggs (Fig. 4). There were significant differences in hatching success when comparing values of naupliar body length at hatching larger and smaller than $100 \mu \mathrm{m}$, taking the covariate of similarity between the AA composition of females and egg into account (ANCOVA, $F_{1,146}=4.9, \mathrm{p}=0.028$ ).

The relationship between hatching success and similarity between the AA composition of females and eggs did not mean that the reduced hatching success observed was exclusively due to an AA imbalance. When the proportion of diatoms in the phytoplankton community (in terms of number of cells) was higher than $70 \%$ (from March to June), low hatching success was observed despite the fact that the similarity between the AA composition of females and food was high (Fig. 5). A comparison of the percentage of diatoms in the phytoplankton (higher and lower than $70 \%$ ), taking the covariate similarity between the AA composition of females and the food into account (ANCOVA, $F_{1,146}=9.2$, $\mathrm{p}=0.003$ ); revealed significant differences in hatching success. At percentages of diatoms lower than $70 \%$, hatching success was significantly correlated with the similarity between AAs of females and seston (Fig. 5).

The reduced naupliar production observed each month as compared to the maximum naupliar production observed during this period (16.8 nauplii female ${ }^{-1}$

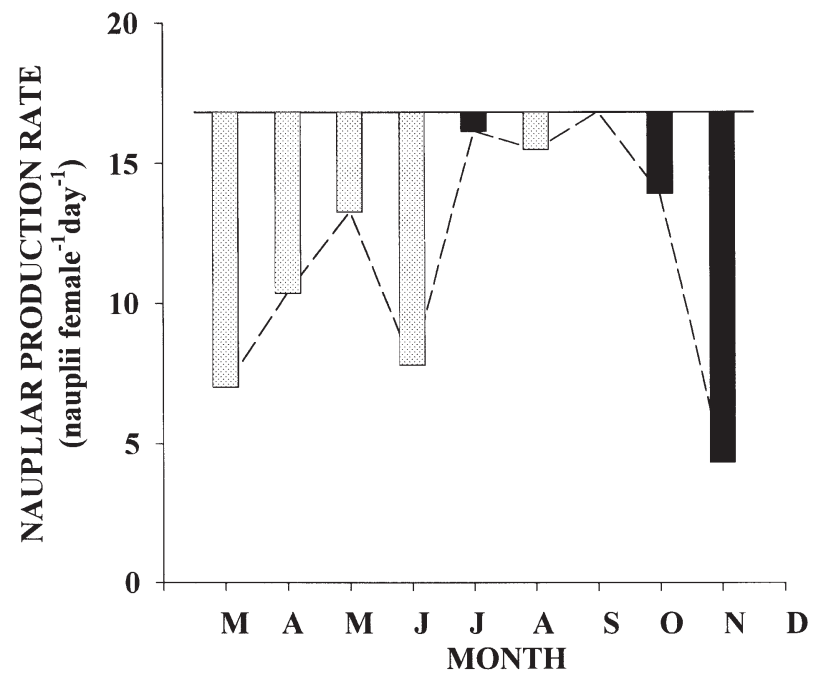

Fig. 6. Monthly naupliar production rates obtained over the sampling period (-- -). Bars represent the difference between maximum naupliar production obtained in the period studied (16.8 nauplii female $\mathrm{e}^{-1} \mathrm{~d}^{-1}$, solid line) and the naupliar production of each month due to food quality (shaded) or food quantity (solid) limitation

$\mathrm{d}^{-1}$ ) was considered to be due to food quality limitation when the similarity between female AAs and egg AAs was higher than 1.5 and due to food quantity limitation when it was lower than 1.5. Fig. 6 shows that food quality mainly limited copepod reproduction in spring and early summer, and food quantity at the end of autumn and early winter. As mentioned above, in winter egg production is affected by temperature, so it was not possible to estimate the possible effect of food quality and/or food quantity on copepod reproductive success.

\section{DISCUSSION}

Although there is no strict homeostasis in the AAs of females, our observations support the hypothesis that AA imbalances can occur and that they may affect copepod reproduction (Anderson \& Hessen 1995, Kleppel et al. 1998, Guisande et al. 1999). Other studies have shown that strict elemental homeostasis is not maintained by zooplankton species (see Sterner \& Schulz 1998). However, as there is greater variability in the chemical content of algae than in that of individual zooplankton species (see Gulati \& DeMott 1997), the penalty is still severe if the diet is not optimally balanced. Demott et al. (1998) found that strict homeostasis in elemental composition is not maintained by Daphnia magna under P limitation, although the growth penalty for this daphnid under low $\mathrm{P}$ conditions is still important. 
The results obtained in this study confirm that chemical composition of copepod eggs is affected by the maternal diet (Guisande \& Harris 1995, Guisande et al. 1999, Laabir et al. 1999). The effect of temperature could explain why egg AAs in winter did not vary according to food source. A comparison of female and egg AAs would seem to be a good indicator of food quality, because these are correlated with both egg production and hatching success.

Copepods were food limited most of the year (Fig. 6). Food quantity and food quality limitation (Checkley 1980, Durbin et al. 1983, Jónasdóttir et al. 1995) have been observed before in copepods. Müller-Navarra \& Lampert (1996), who conducted one of the few seasonal studies to measure the degree of food quality limitation in zooplankton, also observed that both food quantity and food quality affected Daphnia galeata growth. They compared $D$. galeata growth on seston from a lake to growth on a standard high-quality algal food. Their results showed that food quantity accounted for about a $50 \%$ reduction in growth, similar to the food quality effects. Our results lend support to the hypothesis that both food quality and food quantity range between limiting and non-limiting conditions in nature (Sterner \& Schulz 1998). Food quantity affects egg production rate, whereas food quality mainly affects hatching success. Food quality limitation was due to both nutritional deficiencies and the species composition of the phytoplankton community. The low hatching success rates associated with a high proportion of diatoms in the phytoplankton community could be explained by the presence of inhibitory compounds (Miralto et al. 1999).

Food quantity and food quality do not affect copepod reproduction separately, but it seems that copepod fecundity is strongly dependent on food type, and that variation in food quality may interact with food quantity to determine reproductive rates (Cahoon 1981). Our study shows that the way in which food quantity and food quality interact to affect copepod reproduction (Fig. 3) is similar to the hypothetical relationship between food quantity and the specific growth rate of zooplankton with different food types proposed by Sterner \& Schulz (1998). An increase in copepod egg reproduction occurs when food quantity increases, but the intensity of egg production is lower under low food quality conditions. However, at high and low food concentrations there are no differences in copepod reproduction when optimal and suboptimal foods, in terms of their nutritional value, are compared. At high food quantities, if the diversity of the food available to the copepods is high enough and there are no deleterious toxins or inhibitors, copepods might be able to compensate for the low nutritional value and achieve maximal reproduction at high food concentrations.
However, at low food concentrations copepod reproduction is restricted by food quantity, there being no important food quality effects.

Hatching success was also related to the nauplii size at hatching. As there is a positive relationship between egg size and naupliar body length at hatching in copepods (Cooney \& Gehrs 1980, Jónasdóttir 1994, Guisande \& Harris 1995, Guisande et al. 1996), the results seem to confirm that hatching success increases with egg size (Guisande \& Harris 1995). However, the relative importance of egg size on hatching success is lower than the effect of food quality (Fig. 4). This could explain why some field studies did not find any significant relationship between egg size and egg viability in copepod species (Pond et al. 1996, Tang et al. 1998).

In addition to food type effects, if other copepod species show a rigid AA composition, as observed in Euterpina acutifrons, but there are differences in the AAs between different copepod species, copepod reproduction should depend not only on food type but also on the copepod species considered. This is in agreement with the results obtained by Ianora et al. (1996), who showed that the same diet induced considerable interspecific differences in copepod fecundity. If an optimally balanced diet is one which reflects the biochemical composition of the consuming organism, then an approach to the study of food competition among herbivorous copepods such as that proposed by the mechanistic resource competition theory (Tilman 1982) may be needed.

Acknowledgements. We thank J. Turner for useful suggestions and revision of the manuscript, J. M. Cabanas for supplying the temperature data, M. Vázquez for technical support and the crew of the RV 'J.M. Navaz' for helpful assistance. I.E.O. of Vigo provided the research vessels. Phytoplankton abundance data were kindly provided by Centro de Control do Medio Mariño (Xunta de Galicia). This research was supported by a FPU grant to I.M. and a grant from FUNDACIÓN PROVIGO to I.R.

\section{LITERATURE CITED}

Ambler JW (1986) Effect of food quantity and quality on egg production of Acartia tonsa Dana from East Lagoon, Galveston, Texas. Estuar Coast Shelf Sci 23:183-196

Andersen T, Hessen DO (1995) Carbon and nitrogen limitation in marine copepods. J Plankton Res 17:317-332

Cahoon LB (1981) Reproductive response of Acartia tonsa to variations in food ration and quality. Deep-Sea Res 28: 1215-1221

Checkley DM Jr (1980) The egg production of a marine planktonic copepod in relation to its food supply: laboratory studies. Limnol Oceanogr 25:430-446

Cooney JD, Gehrs CW (1980) The relationship between egg size and naupliar size in the calanoid copepod Diaptomus clavipes Schacht. Limnol Oceanogr 25:549-552

D'Apolito LM, Stancyk SE (1979) Population dynamics of Euterpina acutifrons (Copepod: Harpacticoida) from North 
Inlet, South Carolina, with reference to dimorphic males. Mar Biol 54:251-260

DeMott WR, Gulati RD, Siewertsen K (1998) Effects of phosphorus-deficient diets on the carbon and phosphorus balance of Daphnia magna. Limnol Oceanogr 43:1147-1161

Durbin EG, Durbin AG, Smayda TJ, Verity PG (1983) Food limitation of production by adult Acartia tonsa in Narragansett Bay, Rhode Island. Limnol Oceanogr 28:119-1213

Guisande C, Harris RP (1995) Effect of total organic content of eggs on hatching success and naupliar survival in the copepod Calanus helgolandicus. Limnol Oceanogr 40: 476-482

Guisande C, Sánchez J, Maneiro I, Miranda A (1996) Tradeoff between offspring number and offspring size in the marine copepod Euterpina acutifrons at different food concentrations. Mar Ecol Prog Ser 143:37-44

Guisande C, Maneiro I, Riveiro I (1999) Homeostasis in the essential amino acid composition of the marine copepod Euterpina acutifrons. Limnol Oceanogr 44:691-696

Gulati RD, DeMott WR (1997) The role of food quality for zooplankton: remarks on the state-of-art, perspectives and priorities. Freshw Biol 38:753-768

Haq SM (1972) Breeding of Euterpina acutifrons a harpacticid copepod, with special reference to dimorphic males. Mar Biol 15:221-235

Huntley ME, Cimiello P, Lopez MDG (1987) Importance of food quality determining development and survival of Calanus pacificus (Copepoda: Calanoida). Mar Biol 95: 103-113

Hutchinson GE (1967) A treatise on limnology. II. Introduction to lake biology and the limnoplankton. John Wiley \& Sons, New York

Ianora A, Poulet SA (1993) Egg viability in the copepod Temora stylifera. Limnol Oceanogr 38:1615-1626

Ianora A, Mazzocchi MG, Grottoli R (1992) Seasonal fluctuations in fecundity and hatching success in the planktonic copepod Centropages typicus. J Plankton Res 14:1483-1494

Ianora A, Poulet SA, Miralto A, Grottoli R (1996) The diatom Thalassiosira rotula affects reproductive success in the copepod Acartia clausi. Mar Biol 125:279-286

Jónasdóttir SH (1994) Effects of food quality on the reproductive success of Acartia tonsa and Acartia hudsonica: laboratory observations. Mar Biol 121:67-81

Jónasdóttir SH, Kiørboe T (1996) Copepod recruitment and food composition: do diatoms affect hatching success? Mar Biol 125:743-750

Jónasdóttir SH, Fields D, Pantoja S (1995) Copepod egg production in Long Island Sound, USA, as a function of the chemical composition of seston. Mar Ecol Prog Ser 119: 87-98

Kinne O (1977) Cultivation of marine organisms: water-quality management and technology. In: Kinne O (ed) Marine ecology: a comprehensive, integrated treatise on life in oceans and coastal waters, Vol III, Part 2. John Wiley \& Sons, New York, p 19-200

Kleppel GS (1993) On the diets of calanoid copepods. Mar Ecol Prog Ser 99:183-195

Kleppel GS, Burkart CA (1995) Egg production and the nutritional environment of Acartia tonsa: the role of food quality in copepod nutrition. ICES J Mar Sci 52:297-304

Kleppel GS, Burkart CA, Houchin L (1998) Nutrition and the regulation of egg production in the calanoid copepod Acartia tonsa. Limnol Oceanogr 43:1000-1007

Koski M, Breteler WK, Schogt N (1998) Effect of food quality on rate of growth and development of the pelagic copepod Pseudocalanus elongatus (Copepoda, Calanoida). Mar Ecol Prog Ser 170:169-187
Laabir M, Poulet SA, Cueff A, Ianora A (1999) Effect of diet on levels of amino acids during embryonic and naupliar development of the copepod Calanus helgolandicus. Mar Biol 134:89-98

Lowry OH, Rosenbraugh NJ, Farr AL, Randall RJ (1951) Protein measurement with the Folin phenol reagent. J Biol Chem 193:265-275

Markwell MAK, Haas SM, Bieber LL, Tolbert ME (1978) A modification of de Lowry procedure to simplify protein determination in membrane an lipoprotein samples. Ann Biochem 87:206-210

Nejstgaard JC, Solberg PT (1996) Repression of copepod feeding and fecundity by the toxic haptophyte Prymnesium patelliferum. Sarsia 81:339-344

Miralto A, Barone G, Romano G, Poulet SA, Ianora A, Russo GL, Buttino I, Mazzarella G, Laabir M, Cabrini M, Giacobbe MG (1999) The insidious effect of diatoms on copepod reproduction. Nature 402:173-176

Müller-Navarra D, Lampert W (1996) Seasonal patterns of food limitation in Daphnia galeata: separating food quantity and food quality effects. J Plankton Res 18:1137-1157

Pond D, Harris R, Head R, Harbour D (1996) Environmental and nutritional factors determining seasonal variability in the fecundity and viability of Calanus helgolandicus in coastal waters off Plymouth, UK. Mar Ecol Prog Ser 143: $45-63$

Runge JA (1985) Relationship of egg production of Calanus pacificus to seasonal changes in phytoplankton availability in Puget Sound, Washington. Limnol Oceanogr 30: 382-396

Sanders RW, Williamson CE, Stutzman PL, Moeller RE, Goulden CE, Aoki-Goldsmith R (1996) Reproductive success of 'herbivorous' zooplankton fed algal and nonalgal food resources. Limnol Oceanogr 41:1295-1305

Sterner RW (1993) Daphnia growth on varying quality of Scenedesmus: mineral limitation of zooplankton. Ecology 174:2351-2360

Sterner RW, Schulz KL (1998) Zooplankton nutrition: recent progress and reality check. Aquat Ecol 32:261-279

Støttrup JG, Jensen J (1990) Influence of algal diet on feeding and egg-production of the calanoid copepod Acartia tonsa Dana. J Exp Mar Biol Ecol 141:87-105

Tang KW, Dam HG, Feinberg LR (1998) The relative importance of egg production rate, hatching success, hatching duration and egg sinking in population recruitment of two species of marine copepods. J Plankton Res 20: 1971-1987

Tilman D (1982) Resource competition and community structure. Princeton University Press, Princeton, NJ

Turner JT, Tester PA, Hansen PJ (1998) Interactions between toxic marine phytoplankton and metazoan and protistan grazers. In: Anderson DM, Cembella AD, Hallegraeff GM (eds) Physiological ecology of harmful algal blooms. NATO ASI Series, Vol G 41. Springer-Verlag, Berlin, p 453-474

Urabe J, Clasen J, Sterner RW (1998) Phosphorus limitation of Daphnia growth: is it real? Limnol Oceanogr 42: 1436-1443

Van Wandelen $\mathrm{CH}$, Cohen SA (1997) Using quaternary highperformance liquid chromatography eluent systems for separating 6-aminoquinolyl-N-hydroxysuccinimidyl carbamate-derivatized amino acid mixtures. J Chromatogr 763:11-22

Zurlini G, Ferrari I, Nassogne A (1978) Reproduction and growth of Euterpina acutifrons (Copepoda: Harpacticoida), under experimental conditions. Mar Biol 46:59-64

Submitted: November 12, 1999; Accepted: March 16, 2000

Proofs received from author(s): August 7, 2000 